\title{
Appraisement function of Coenzyme Q10 on body weight changes blood serum biochemical parameters in resembling type 2 diabetic male rats
}

\author{
Alireza Shahriary $^{1^{*}}$, Masood Khakzadihe ${ }^{2}$, Yunes Panahi ${ }^{1}$ \\ ${ }^{1}$ Chemical Injuries Research Center, Baqiyatallah University of Medical Sciences, Tehran, Iran. \\ ${ }^{2}$ young Researchers and Elite Club, Tabriz Branch, Islamic Azad University, Tabriz, Iran.
}

\section{ARTICLE INFO \\ Article history: \\ Received on: 15/08/2016 \\ Revised on: 18/09/2016 \\ Accepted on: 03/10/2016 \\ Available online: $31 / 01 / 2017$}

Key words:

Diabetes, Coenzyme Q10,

Rat, Biochemical,

Antioxidant.

\begin{abstract}
Diabetes mellitus is a metabolic disorder characterized by hyperglycemia and inadequacy of secretion or action of endogenous insulin. Feeding fructose or sucrose can provide model of hyperlipidemia, hyperglycemia and insulin resistance. This research conducted to investigate how CoQ10 can improve the antioxidant defense system and decrease of abnormalities in carbohydrate, protein and lipids metabolism in rat. First group as control rats with i.p. injection of saline daily. Second group fed on normal diet and supplemented by $10 \%$ fructose in drinking water ad libitum with i.p. injection of saline daily. Third group as Fructose fed rats treated with coenzyme Q10, $10 \mathrm{mg} / \mathrm{kg}$ i.p. daily. After 30 days blood samples were analyzed. Blood serum glucose assay was performed using GOD-POP method. cholesterol and TG review were performed using enzymatic method, HDL using phosphortungstate method, TP using biuret method, albumin using BCG method, insulin and leptin using RIMA method and MDA using TCA method. Using CoQ10 improved carbohydrate, lipid and protein metabolism and decreased oxidative stress. But recuperation did not reach to recorded level in control group.
\end{abstract}

\section{INTRODUCTION}

The worldwide occurrence of diabetes mellitus has significantly increased throughout the past two decades, firmly establishing the condition as one of the most 21 st century significant health burdens. By the year 2025, about 300,000,000 individuals are predicted to have diabetes, with the mass of these suffering from diabetes type 2 (Shaw et al., 2010). Diabetes mellitus is a metabolic disorder characterized by hyperglycemia and inadequacy of secretion or action of endogenous insulin. However the diabetes etiology is not well defined but viruses, autoimmune disease and environmental conditions have been implicated (Kataoka et al., 1983; Shewade et al., 2001). Increased oxidative stress is a widely accepted contributor in the expansion

\section{* Corresponding Author}

Alireza Shahriary, Chemical Injuries Research Center, Baqiyatallah University of Medical Sciences, Tehran, Iran Email: masood.khakzadihe@gmail.com and development of diabetes and its complications (Ceriello, 2000; Baynes, 1991). Diabetes is usually accompanied by increased production of free radicals (Baynes and Thorpe, 1999, Young et al., 1995) or impaired antioxidant defenses (Halliwell and Gutteridge, 1990; McLennan, 1991). Oxidative stress can increase reactive oxygen species in high free fatty acid condition that mechanism of this oxidative stress depends on increase mitochondrial uncoupling of oxidative phosphorylation and $\beta$ oxidation leading to increasing production of reactive oxygen species (Patane et al., 2002). Also through auto-oxidation, oxidative phosphorylation, glycosylation and glycosamine pathways in high glucose range can product mitochondrial reactive oxygen species that causes oxidative stress (Giacco and Brownlee 2010). Coenzyme Q (2-methyl-5,6-dimethoxy-1,4-benzoquinone), soluble natural fat quinine, is a ubiquitous and endogenous lipidsoluble antioxidant found in plant as well as in human and animal organisms (Kismali, 2009). CoQ10 is important for optimal biological function. 
It is a component of the oxidative phosphorylation process in mitochondria that converts the energy in fatty acids and carbohydrates into Adenosine Three Phosphate (ATP) to drive cellular synthesis (Trunen, 2004).

Break the continuity of the extra production of oxidants by electron transport chain of mitochondria would normalize the pathways involved in development of oxidative stress (Kucharska et al., 2000). In diabetes condition oxidative phosphorylation is significantly reduced, afterwards production of adenosine three phosphate is reduced along with decreased level of CoQ10 (Kucharska et al., 2000). One of the other important roles of CoQ10 is inhibit certain enzymes that plays in formation of free radicals and so attenuates oxidative stress (Moazen et al., 2015, Noh et al., 2013, Olatunji and Soladoye, 2007; Huang et al., 2004). Feeding fructose or sucrose can provide model of hyperlipidemia, hyperglycemia and insulin resistance (Olatunji and Soladoye, 2007; Huang et al., 2004; Rajasekar and Anuradha, 2007; Thorburn, 1989). This research conducted to investigate how CoQ10 can improve the antioxidant defense system and decrease of abnormalities in carbohydrate, protein and lipids metabolism in rat.

\section{MATERIAL AND METHODS}

\section{Animal and breeding}

For this study 45 male adult rats were divided in to three groups (each group $\mathrm{n}=15$ ). They were housed three per wirebottomed, stainless steel cages to minimize coprophagy in a well ventilated. There were no significant differences on weight (The average body weight 180 to 220 gram), age, appearance and environment of rats. The environment was exposed to 12-hour lighting and 12-hour dark during the experiment for each group. The room temperature was $22 \pm 2$ Degrees Celsius during the experimental period with $58-62 \%$ relative humidity. Using fed was according to NRC and presented in table 1 . The consumed water was the Tabriz city tap water which was re-refined using carbon and sand filters.

\section{Experimental groups}

First group as control rats fed on normal diet and water ad libitum with i.p. injection of saline daily. Second group as Fructose fed control rat group fed on normal diet and supplemented by $10 \%$ fructose in drinking water ad libitum with i.p. injection of saline daily. Third group as Fructose fed rats treated with coenzyme Q10, $10 \mathrm{mg} / \mathrm{kg}$ i.p. daily (Heibashy et al., 2009, Kismali 2009, Rauscher et al., 2001). The used coenzyme Q10 in this study was from metagenic company. The injection amount of saline in first and second groups was as same as coenzyme Q10 in third group.

Table1: Ingredient - Diet used for rat breeding in this study.

\begin{tabular}{ll}
\hline Ingredient & Diet \\
\hline Basic Diet, $\mathrm{g} / \mathrm{kg}$ diet & \\
\hline Dried skim milk & $50 \mathrm{~g}$ \\
\hline
\end{tabular}

\begin{tabular}{ll}
\hline Fish meal (60\% protein) & $100 \mathrm{~g}$ \\
Soybean meal (48\% protein) & $120 \mathrm{~g}$ \\
Alfalfa meal, dehydrated (17\% protein) & $40 \mathrm{~g}$ \\
Corn gluten meal (60\% protein) & $30 \mathrm{~g}$ \\
Ground \#2 yellow shelled corn & $245 \mathrm{~g}$ \\
Ground hard winter wheat & $230 \mathrm{~g}$ \\
Ground whole oats & - \\
Wheat middlings & $100 \mathrm{~g}$ \\
Brewer's dried yeast & $20 \mathrm{~g}$ \\
Dry molasses & $15 \mathrm{~g}$ \\
Soybean oil & $25 \mathrm{~g}$ \\
Salt & $5 \mathrm{~g}$ \\
Dicalcium phosphate & $12.5 \mathrm{~g}$ \\
Ground limestone & $5 \mathrm{~g}$ \\
Mineral premix & $1.2 \mathrm{~g}$ \\
Vitamin premix & $1.3 \mathrm{~g}$ \\
\hline Mineral Premix, mg/kg diet & \\
\hline Cobalt (as cobalt carbonate) & $0.44 \mathrm{mg}$ \\
Copper (as copper sulfate) & $4.4 \mathrm{mg}$ \\
Iron (as iron sulfate) & $132.3 \mathrm{mg}$ \\
Manganese (as manganous oxide) & $66.2 \mathrm{mg}$ \\
Zinc (as zinc oxide) & $17.6 \mathrm{mg}$ \\
Iodine (as calcium iodate) & $1.54 \mathrm{mg}$ \\
\hline Vitamin Premix, per $k g$ diet & \\
\hline Stabilized vitamin A palmitate or stearate & $6,060.00 \mathrm{IU}$ \\
Vitamin D (D-activated animal sterol) & $5,070.00 \mathrm{IU}$ \\
Vitamin K (menadione activity) & $3.09 \mathrm{mg}$ \\
All-rac- $\alpha$-tocopheryl acetate & $22.10 \mathrm{mg}$ \\
Choline chloride & $617.00 \mathrm{mg}$ \\
Folic acid & $2.43 \mathrm{mg}$ \\
Niacin & $33.10 \mathrm{mg}$ \\
Ca- -pantothenate & $19.80 \mathrm{mg}$ \\
Pyridoxine-HCl & $1.87 \mathrm{mg}$ \\
Riboflavin supplement & $3.75 \mathrm{mg}$ \\
Thiamin mononitrate & $11.0 \mathrm{mg}$ \\
$d$-Biotin & $0.15 \mathrm{mg}$ \\
Vitamin B12 supplement & $0.004 \mathrm{mg}$ \\
\hline
\end{tabular}

\section{Blood serum analyzing}

After 29 days, blood sampling was taken on the 30th day from groups. The blood was added into the serum tube manufactured by Euro Tube ${ }^{\circledR}$ Company. After clotting, the blood was centrifuged with the speed of $3000 \mathrm{rpm}$ for 10 minutes and the serum was removed. Blood serum glucose assay was performed using GOD-POP method. Also cholesterol and triglyceride review were performed using enzymatic method, HDL using phosphortungstate method, total protein using biuret method, albumin using BCG method, insulin and leptin using radioimmunoassay method and malondialdehyde using TCA method. Serum LDL, VLDL and Atherogenic Index were calculated by following formulas:

$$
\begin{aligned}
& \text { LDL }=\frac{\text { Total Serum Cholesterol-Total Serum Triglyceride }}{5-\text { Total Serum HDL }} \\
& \text { VLDL }=\frac{\text { Total Serum Triglyceride }}{5} \\
& \text { Atherogenic Index }=\frac{\text { Total serum Triglyceride }}{\text { Total Serum HDL.C }}
\end{aligned}
$$

All the introducing kits in this study are manufactured by Randox or Pars Azmoon Company. 


\section{Ethics statement}

This experiment was carried out in according to recommendations in the guide for the care and use of laboratory animals of the Islamic Azad University and under regulations of animal care and use of college of veterinary medicine, Tabriz Branch, Islamic Azad University (Dr. Soheil Vazifehdoost). All surgery was performed under deep sodium pentobarbital anesthesia and all efforts were made to minimize suffering.

\section{Statistical analysis}

Data were analyzed using statistical software, SPSS version 19.00 using Duncan's multiple range ANOVA test. Data with $5 \%$ level $(\mathrm{p}<0.05)$ of significance were considered. Percent of parameter level changes compared to control group calculated.

\section{RESULTS AND DISCUSSION}

According to table 2, 3\& 4 data with different word in same row (A, B and C) has significant difference in $\mathrm{p}<0.05$. Percent of studied parameters changes compared with control group were present in tables. The results of body weight changes after using Coenzyme Q10 in resembling diabetes type 2 in male rats presented in table 2 . There were significant differences on body weight changes between groups $(\mathrm{p}<0.05)$.
There was significant increase in body weight of rats fed on fructose and fructose plus CoQ10. Also using CoQ10 significantly decreased body weight of fructose fed plus CoQ10 group compared fructose fed alone $(p<0.05)$. Much of the evidences prove diabetes mellitus type 2 causes oxidative stress, elevated glucose range and free fatty acids level. The structure of insulin contains determinants of fold ability, receptor binding, trafficking and self assembly. Insulin is the biosynthetic product of a single-chain precursor, preproinsulin, whose proteolytic processing is coupled to trafficking between cellular compartments (Weiss 2013).

Insulin as hormone is a serious energy homeostasis regulator; it stimulates uptake of glucose, free fatty acids and amino acids by tissues. The increased levels of glucose and insulin parameters in fructose fed rats in this study were in relation with elevated leptin level in the same group, compared to control, proved the communication between leptin and insulin secretion in energy homeostasis regulation (Margetic et al., 2002). Blunted insulin release as a result of pancreatic islets chronic exposure to either high glucose or free fatty acid levels (gluco- and lipotoxicity) is associated with a reduction in adenosine tree phosphate synthesis as a result of the inability of $\beta$-cells to increase the adenosine tree phosphate levels in response to glucose stimulation(Giovanni et al., 2002).

Table 2: Results of body weight changes after using Coenzyme Q10 in resembling diabetes type 2 in male rats.

\begin{tabular}{|c|c|c|c|c|}
\hline \multirow{2}{*}{ Parameter } & \multirow{2}{*}{ Analyzed form } & \multicolumn{3}{|c|}{ Experimental Groups } \\
\hline & & Normal & Fructose Fed & Fructose Fed+CoQ10 \\
\hline Body weight & Mean \pm SD & $241.30 \pm 3.51 \mathrm{~A}$ & $374.20 \pm 2.89 \mathrm{~B}$ & $314.30 \pm 2.99 \mathrm{C}$ \\
\hline Gram/rat & Percent of change & - & $55.70 \%$ & $30.25 \%$ \\
\hline
\end{tabular}

Table 3: Results of hormones changes after using Coenzyme Q10 in resembling diabetes type 2 in male rats.

\begin{tabular}{|c|c|c|c|c|}
\hline \multirow{2}{*}{ Parameter } & \multirow{2}{*}{ Analyzed form } & \multicolumn{3}{|c|}{ Experimental Groups } \\
\hline & & Normal & Fructose Fed & Fructose Fed+CoQ10 \\
\hline \multirow{2}{*}{ Insulin (mIU/ml) } & Mean \pm SD & $25.25 \pm 1.18^{\mathrm{A}}$ & $42.01 \pm 1.88^{\mathrm{B}}$ & $33.08 \pm 1.35^{\mathrm{C}}$ \\
\hline & Percent of change & - & $66.38 \%$ & $31.00 \%$ \\
\hline \multirow{2}{*}{ Leptin (ng/ml) } & Mean \pm SD & $3.32 \pm 0.11^{\mathrm{A}}$ & $5.64 \pm 0.32^{\mathrm{B}}$ & $8.11 \pm 0.94^{\mathrm{C}}$ \\
\hline & Percent of change & - & $69.87 \%$ & $144.28 \%$ \\
\hline
\end{tabular}

Table 4: Results of biochemical parameters changes after using Coenzyme Q10 in resembling diabetes type 2 in male rats.

\begin{tabular}{|c|c|c|c|c|}
\hline \multirow{2}{*}{ Parameter } & \multirow{2}{*}{ Analyzed form } & \multicolumn{3}{|c|}{ Experimental Groups } \\
\hline & & Normal & Fructose Fed & Fructose Fed+CoQ10 \\
\hline \multirow{2}{*}{$\begin{array}{l}\text { Glucose } \\
(\mathrm{mg} / \mathrm{dl})\end{array}$} & Mean \pm SD & $114.17 \pm 3.01^{\mathrm{A}}$ & $241.31 \pm 4.44^{\mathrm{B}}$ & $169.90 \pm 2.85^{\mathrm{C}}$ \\
\hline & Percent of change & - & $111.36 \%$ & $48.81 \%$ \\
\hline \multirow{2}{*}{$\begin{array}{l}\text { Total Protein } \\
(\mathrm{g} / \mathrm{dl})\end{array}$} & Mean \pm SD & $5.66 \pm 0.31^{\mathrm{A}}$ & $6.89 \pm 0.85^{\mathrm{B}}$ & $5.89 \pm 0.59^{\mathrm{A}}$ \\
\hline & Percent of change & - & $21.73 \%$ & $4.06 \%$ \\
\hline \multirow{2}{*}{$\begin{array}{l}\text { Albumin } \\
(\mathrm{g} / \mathrm{dl})\end{array}$} & Mean \pm SD & $3.41 \pm 0.25^{\mathrm{A}}$ & $2.89 \pm 0.59^{\mathrm{B}}$ & $3.35 \pm 0.85^{\mathrm{A}}$ \\
\hline & Percent of change & 00.00 & $-15.24 \%$ & $-1.75 \%$ \\
\hline \multirow{2}{*}{$\begin{array}{l}\text { Cholesterol } \\
(\mathrm{mg} / \mathrm{dl})\end{array}$} & Mean \pm SD & $60.11 \pm 1.82^{\mathrm{A}}$ & $130.41 \pm 2.90^{\mathrm{B}}$ & $97.03 \pm 2.88^{\mathrm{C}}$ \\
\hline & Percent of change & 00.00 & $116.95 \%$ & $61.42 \%$ \\
\hline \multirow{2}{*}{$\begin{array}{l}\text { Triglyceride } \\
(\mathrm{mg} / \mathrm{dl})\end{array}$} & Mean \pm SD & $64.21 \pm 3.01^{\mathrm{A}}$ & $153.28 \pm 3.42^{\mathrm{B}}$ & $99.48 \pm 3.32^{C}$ \\
\hline & Percent of change & 00.00 & $138.71 \%$ & $59.92 \%$ \\
\hline \multirow{2}{*}{$\begin{array}{l}\text { High Density Lipoprotein } \\
(\mathrm{mg} / \mathrm{dl})\end{array}$} & Mean \pm SD & $17.21 \pm 0.48^{\mathrm{A}}$ & $9.52 \pm 0.82^{B}$ & $14.28 \pm 0.81^{C}$ \\
\hline & Percent of change & 00.00 & $-44.68 \%$ & $-17.02 \%$ \\
\hline \multirow{2}{*}{$\begin{array}{l}\text { Low Density Lipoprotein } \\
(\mathrm{mg} / \mathrm{dl})\end{array}$} & Mean \pm SD & $30.41 \pm 0.91^{\mathrm{A}}$ & $88.30 \pm 1.21^{\mathrm{B}}$ & $60.46 \pm 1.22^{C}$ \\
\hline & Percent of change & 00.00 & $190.36 \%$ & $98.81 \%$ \\
\hline \multirow{2}{*}{$\begin{array}{l}\text { Very Low Density Lipoprotein } \\
(\mathrm{mg} / \mathrm{dl})\end{array}$} & Mean \pm SD & $11.38 \pm 0.72^{\mathrm{A}}$ & $28.36 \pm 0.94^{\mathrm{B}}$ & $20.21 \pm 0.72^{\mathrm{C}}$ \\
\hline & Percent of change & 00.00 & $149.20 \%$ & $77.59 \%$ \\
\hline \multirow{2}{*}{ Malondialdehyde (nmol/ml) } & Mean \pm SD & $34.23 \pm 12.32^{\mathrm{A}}$ & $69.30 \pm 10.53^{\mathrm{B}}$ & $47.19 \pm 13.25^{\mathrm{C}}$ \\
\hline & Percent of change & 00.00 & $102.45 \%$ & $37.86 \%$ \\
\hline \multirow{2}{*}{ Atherogenic Index } & Mean \pm SD & $3.74 \pm 0.11^{\mathrm{A}}$ & $16.11 \pm 0.42^{\mathrm{B}}$ & $7.01 \pm 0.28^{C}$ \\
\hline & Percent of change & 0.00 & $330.47 \%$ & $87.43 \%$ \\
\hline
\end{tabular}


According to an i.p glucose tolerance test, the treatment with antioxidants retained glucose-stimulated insulin secretion and moderately decreased blood glucose levels (Kaneto et al., 2002). Histological analyses of the pancreata revealed that the $\beta$-cell mass was significantly larger in the mice treated with the antioxidants, and the antioxidant treatment suppressed apoptosis in $\beta$-cells without changing the rate of $\beta$-cell proliferation. The antioxidant treatment also preserved the amounts of insulin content and insulin mRNA, making the extent of insulin degranulation less evident. Taken together, oxidative stress and consequent activation of the JNK pathway are involved in progression of $\beta$-cell dysfunction found in diabetes (Kaneto et al., 2002). In the current study, CoQ10 treatment reduced the blood glucose levels in fructose fed animals without affecting hyperinsulinemia. Under diabetic condition, JNK is activated by oxidative stress and involved in the suppression of insulin gene expression (Kaneto et al., 2002).

Leptin levels in the white adipose tissue and plasma are linked to the energy sources, so that leptin increases in fatness or obesity and decreases during fasting. Leptin deficiency has been associated with hyperlipidemia, insulin resistance, hyperphagia, impaired in thermogenesis, and central hypogonadism (Zhang et al., 1994, Farooqi et al., 2002). Leptin receptor-mediated JAKSTAT signaling is necessary for regulation of body weight. Leptin stimulated PI3K signaling is substantial for glucose metabolism regulation. Leptin can limits agglomeration of triglycerides (TG) in skeletal muscle and liver via a combination between direct activation of AMPK and indirect actions mediated via CNS pathways, therewith developing sensitivity of insulin (Kondo et al., 2002). Also it has been proven that leptin can affect on fatty acid metabolism, resulting in an increase in capacity to oxidize free acid and so lowering TG stores (Duck 2005). Thus according to results of table 3 and 4 also Duck review (Duck 2005), reducing TG level in fructose fed with CoQ10 group compared with fructose fed group is due to suppressive effects of serum leptin. In addition, leptin modifies pancreatic $\beta$-cells function via direct actions (Karpichev et al., 2002) and indirectly via CNS pathways (Kharroubi et al., 2003). Leptin sensitivity debilitation in brain leads to accumulation of excess triglyceride in adipose tissue, liver and pancreas, resulting in impaired insulin secretion and sensitivity (Saito et al., 1999).

Triglyceride reducing effects of coenzyme Q10 is the result of low density lipoprotein specific antioxidant activity also increased cellular antioxidant status (Zahedi et al., 2014). Q10 could enhance fatty acid oxidation through AMPK- mediated (AMP-activated-protein-kinase) peroxisome proliferator-activated receptor $\alpha(\mathrm{PRAR} \alpha)$ stimulation (Lee et al., 2012) that increases lipoprotein lipase and APO-AV expression. This may decreases TG and VLDL Levels (Suckling and Jackson, 1993). It has been proven that consuming of CoQ10 for 4 weeks significantly reduces the serum levels of triglycerides, total cholesterol, low density lipoprotein cholesterol (LDL) and very low density lipoprotein cholesterol (VLDL) and increases HDL in streptozotocin induced diabetic rats (Modi et al., 2006). It is provided; high fat feeding impairs glucose-induced insulin secretion only in the context of chronic hyperglycemia in Goto-Kakizaki rat islets. These effects are not mediated by triglyceride accumulation in islets but are associated with changes in uncoupling protein 2 (UCP-2) expressions (Briaud et al., 2002).

There were significant differences between serum albumin and total protein levels $(\mathrm{P}<0.05)$. Blood serum total protein significantly reduced in CoQ10 treated rats compared with fructose fed only. There were significant increase between both fructose fed group and CoQ10 treated group compared with control group. But in albumin parameter we observed marked decreases between studied groups and control group. Microalbuminuria is a symptom for diabetic nephropathy and cardiovascular disease in patients with type 1 and 2 diabetes (Derakhshan et al., 2007). In both, type 1 and type 2 diabetics the total plasma proteins and urinary albumin excretion rate significantly increases, while serum albumin significantly decreases (Rehman et al., 2012, Upchurch et al., 1997). Increased plasma concentration of acute phase proteins have been reported in adult patients with either type 2 or 1 diabetes (Ladeia et al., 2006). Diabetics may exhibit hypergammaglobulinemia like immunoglobulin A (IgA) and immunoglobulin G (IgG) (Ardavi et al., 1994). Antioxidant role of CoQ10 can decrease oxidative stress and adjust oxidative stress also can play important role in acute phase proteins decrease.

Malondialdehyde is a highly reactive three carbon dialdehyde produced as a byproduct of polyunsaturated fatty acid peroxidation (Zhang et al., 2002) and also during metabolism of arachidonic acid for the synthesis of prostaglandins (Choi et al., 2003). Malondialdehyde can combine with several functional groups on molecules including DNA, RNA, lipoproteins and proteins (Rumley et al., 2004).

The monitoring and measurement of malondialdehyde levels in biological materials can be used as an important index of lipid peroxidation in vitro and in vivo for several diseases. Previous studies have shown elevated levels of malondialdehyde in plasma of both Type 1 and Type 2 diabetic subjects (Noberasco et al., 1991). CoQ10 supplementation had decreased oxidative stress as measured by malondialdehyde levels in healthy men (Gómez-Díaz et al., 2003). Malondialdehyde is a product of lipid peroxidation. Lipid peroxidation is a well established mechanism of cellular injury in both human and animals and is used as an index and indicator of oxidative stress in cell and tissue. Malondialdehyde can be generated during cyclooxygenase catalysis in human and animal platelets, formation from prostaglandin endoperoxide $\left(\mathrm{PGH}_{2}\right)$, catalyzed by thromboxane synthase (Diczfalusy et al., 1977) and in liver cell (Plastaras et al., 2000) by segregation of $\mathrm{PGH}_{2}$.

\section{CONCLUSION}

Coenzyme Q10 in resembling type 2 diabetic rats improved metabolism of carbohydrate, lipid and protein and decreased oxidative stress. But recuperation did not reach to recorded level in control group. 
Financial support and sponsorship: Nil.

Conflict of Interests: There are no conflicts of interest.

\section{REFERENCES}

Ardavi MS, Nasrat HA, Bahnassy AA. Serum Immunoglobulin concentrations in diabetic patients. Diabetic Med, 1994; 11: 384-87.

Baynes JW. Role of oxidative stress in development of complications in diabetes. Diabetes, 1991; 40: 405-412.

Baynes JW, Thorpe SR. Role of oxidative stress in diabetic complications: A new perspective on an old paradigm. Diabetes, 1999; 48: $1-9$.

Briaud I, Kelpe CL, Johnson LM, Tran POT, Poitout V. Differential effects of hyperlipidemia on insulin secretion in islets of langerhans from hyperglycemic versus normoglycemic rats. Diabetes, 2002; 51: 662-668.

Ceriello A. Oxidative stress and glycemic regulation. Metabolism, 2000; 49: 27-29.

Choi JW, Kim DJ, Rhim JH, Chung JH, Chung HK. Generation and characterization of IgG monoclonal antibodies specific for malondialdehyde. Hybrid Hybridomics, 2003; 22: 259-262.

Derakhshan A. Akhawan M. Karamifar H. Evaluation of Microalbuminuria 4 to 6 years following Type-1 Diabetes in Children, Iran J Ped, 2007; 17: 252-6.

Diczfalusy U, Falardeau P, Hammarstrom S. Conversion of prostaglandin endoperoxides to C17-hydroxy acids catalyzed by human platelet thromboxane synthase. FEBS Lett, 1977; 84: 271-274.

Duck DJ. Science Rev, 2005; 33: 189-194.

Farooqi IS, Matarese G, Lord GM. Beneficial effects of leptin on obesity, $\mathrm{T}$ cell hyporesponsiveness, and neuroendocrine/metabolic dysfunction of human congenital leptin deficiency. J Clin Invest, 2002; 110: $1093-1103$

Giacco F, Brownlee M. Oxidative stress and diabetic complications. Circ Res, 2010; 107: 1058-1070.

Gómez-Díaz C, Burón MI, Alcaín FJ, González-Ojeda R, González-Reyes JA, Bello RI, Hermán MD, Navas P, Villalba JM. Effect of dietary coenzyme $\mathrm{Q}$ and fatty acids on the antioxidant status of rat tissues. Protoplasma, 2003; 221: 11-17.

Halliwell B, Gutteridge JM. Role of free radicals and catalytic metal ions in human disease: An overview. Meth Enzymol, 1990; 186: 1 85.

Heibashy MIA, El-Nahla AM, Mazen GMA, Shahin MIM. Assessment role of coenzyme Q10 on some physiological and biochemical parameters in resembling diabetic rats. SCVMJ, 2009; 40: 61-76.

Huang BW, Chiang MT, Yao HT, Chiang W. The effect of high-fat and high-fructose diets on glucose tolerance and plasma lipid and leptin levels in rats. Diabetes, 2004; 6: 120-126.

Kaneto $\mathrm{H}, \mathrm{Xu} \mathrm{G}$, Fuji N, Kim S, Bonner WS, Weir GC. Involve-ment of $\mathrm{C}$-Jun $\mathrm{N}$-terminal kinase in oxidative stress mediated suppression of insulin gene expression. J Biol Chem, 2002; 277: 3001030018.

Karpichev IV, Cornivelli L, Small GM. Multiple regulatory roles of a novel Saccharomyces cerevisiae protein, encoded by YOL002c, in lipid and phosphate metabolism. J Biol Chem, 2002; 277: 12152-12162.

Kataoka S, Satoh J, Fujiya H, Toyota T, Suzuki R, Itoh K, Kumagai K. Immunologic aspects of the nonobese diabetic (NOD) mouse. Abnormalities of cellular immunity. Diabetes, 1983; 32: 247-253.

Kharroubi I, Rasschaert J, Eizirik DL, Cnop M. Expression of adiponectin receptors in pancreatic $\beta$ cells. Biochem Biophys Res Commun, 2003; 312:1118-22

Kismali G. Effects of coenzyme Q10 on blood biochemistry in rats Kafkas Univ Vet Fak Derg, 2009; 15:191-194.

Kondo H, Shimomura I, Matsukawa Y, et al., Association of adiponectinmutationwith type 2 diabetes: a candidate gene for the insulin resistance syndrome. Diabetes, 2002; 51: 2325-2328.

Kucharska J, Braunova Z, O Uliena I. Deficit of coenzyme Q10 in heart and liver mitochondria of rats with streptozotocin-induced diabetes. Physiol Res, 2000; 49: 411-418.
Ladeia A, Stefanelli E, Ladeia-frota C, Moreira A, Hiltner A, Adan L. Association between elevated serum C-reactive protein and triglyceride levels in young subjects with type-1 diabetes. Diabetes Care 2006; 29: 424-6.

Lee SK, Lee JO, Kim JH, Kim N, You GY, Moon JW, Sha J, Kim SJ, Lee YW, Kang HJ, Park SH, Kim HS. Coenzyme Q10 increases the fatty acid oxidation through AMPK-mediated PPARalpha induction in 3 T3-L1 preadipocytes. Cell Signal, 2012; 24: 2329-2336.

Margetic S, Gazzola C, Pegg GG, Hill RA. Leptin: a review of its peri-pheral actions and interactions. Int J Obes, 2002; 26: 1407-1433.

McLennan SV, Heffernan S, Wright L, Rae C, Fisher E, Yue DK, Turtle JR. Changes in hepatic glutathione metabolism in diabetes. Diabetes, 1991; 40: 344-348.

Moazen M, Mazloom Z, Ahmadi A, Dabbaghmanesh MH, Roosta S. Effect of coenzyme Q10 on glycaemic control, oxidative stress and adiponectin in type 2 diabetes. J Pak Med Assoc, 2015; 65:404-8.

Modi K, Santani D, Goyal R, Bhatt P. Effect of coenzyme Q10 on catalase activity and other antioxidant parameters in streptozotocininduced diabetic rats. Biol Trace Elem Res. 2006; 109: 25-33.

Noberasco G, Odetti P, Boeri D, Maiello M, Adezati L. Malondialdehyde (MDA) level in diabetic subjects. Relationship with blood glucose and glycosylated hemoglobin. Biomed and Pharmacother, 1991; 45: 193-196.

Noh YH, Kim KY, Shim MS, Choi SH, Choi S, Ellisman MH, Weinreb RN, Perkins GA, Ju WK. Inhibition of oxidative stress by coenzyme Q10 increases mitochondrial mass and improves bioenergetic function in optic nerve head astrocytes. Cell Death Dis, 2013; 4: 820.

Olatunji LA, Soladoye AO. Increased magnesium intake prevents hyperlipidemia and insulin resistance and reduces lipid peroxidation in fructose-fed rats. Pathophysiology, 2007; 14: 11-15.

Patane` G, Anello M, Piro S, Vigneri R, Purrello F, Rabuazzo AM. Role of ATP Production and uncoupling protein-2 in the Insulin secretory defect induced by chronic exposure to high glucose or free fatty acids and effects of peroxisome proliferator-activated receptor- $\gamma$ inhibition. Diabetes, 2002; 51: 2749-2756.

Plastaras JP, Guengerich FP, Nebert DW, Marnett LJ. Xenobiotic-metabolizing cytochromes $\mathrm{P} 450$ convert prostaglandin endoperoxide to hydroxyheptadecatrienoic acid and the mutagen, malondialdehyde. J Biol Chem, 2000; 275: 11784-11790.

Rajasekar P, Anuradha CV. Effect of L-Carnitine on Skeletal Muscle Lipids and Oxidative Stress in Rats Fed High-Fructose Diet. Exp Diabetes Res, 2007; 72741: 1-8.

Rauscher FM, Sanders RA, Wat-kins JB. Effects of coenzyme Q10 treat-ment on antioxidant pathways in normal and streptozotocininduced diabetic rats. J Biochem Mol. Toxicol, 2001; 15: 41-45.

Rehman A, Zamir S, Bhatti A, Saeed Jan S, Ali S, Wazir F. Evaluation of albuminuria, total plasmaproteins, and serum albumin in diabetics. GJMS, 2012; 10: 198-200

Rumley AG, Woodward M, Rumley A, Rumley J, Lowe GDO Plasma lipid peroxides: relationship to cardiovascular risk factors and prevalent cardiovascular disease. QJM, 2004; 97: 809-816.

Saito K, Tobe T, Yoda M, Nakano Y, Choi-Miura NH, Tomita M. Regulation of gelatin-binding protein 28 (GBP28) gene expression by C/EBP. Biol Pharm Bull, 1999; 22: 1158-62.

Shaw JE, Sicree RA, Zimmet PZ. Global estimates of the prevalence of diabetes for 2010 and 2030. Diabetes Res Clin Pract, 2010; 87: 4-14

Shewade Y, Tirth S, Bhonde RR. Pancreatic islet-cell viability, functionality and oxidative status remain unaffected at pharmacological concentrations of commonly used antibiotics in vitro. J Biosci, 2001; 26 : 349-355

Suckling KE, Jackson B. Animal models of human lipid metabolism. Prog Lipid Res, 1993; 32: 1-24.

Thorburn AW, Storlien LH, Jenkins AB, Khouri S, Kraegen EW. Fructose-induced in vivo insulin resistance and elevated plasma triglyceride levels in rats. Am Jou Clin Nut, 1989; 49 115-116.

Trunen M, Olsson J, Dallner G. Metabolism and function of coenzyme Q. BBA- Biomembranes, 2004; 1660: 171-199. 
Upchurch GR, Keagy BA, Johnson G. An acute phase reaction in diabetic patients with foot ulcers. Cardiovasc Surg, 1997; 5: 32-6.

Weiss MA. Diabetes mellitus due to the toxic misfolding of proinsulin variants. FEBS Lett, 2013; 587: 1942-1950.

Young IS, Tate S, Lightbody JH, McMaster D, Trimble ER. The effects of desferrioxamine and ascorbate on oxidative stress in the streptozotocin diabetic rat. Free Radic Biol Med, 1995; 18: 833-840.

Zahedi H, Eghtesadi S, Seifirad S, Rezaee N, Shidfar F, Heydari I, Golestan B, Jazayeri S. Effects of CoQ10 Supplementation on Lipid Profiles and Glycemic Control in Patients with Type 2 Diabetes: a randomized, double blind, placebo-controlled trial. J Diabetes Metab Disord, 2014; 13: 81 .

Zhang Y, Chen SY, Hsu T, Santella RM. Immunohistochemical detection of malondialdehyde-DNA adducts in human oral mucosa cells. Carcinogenesis, 2002; 23: 207-211.
Zhang Y, Proenca R, Maffei M, Barone M, Leopold L, Friedman JM. Positional cloning of the mouse obese gene and its human homologue. Nature, 1994; 372: 425-432.

\section{How to cite this article:}

Shahriary A, Khakzadihe M, Panahi Y. Appraisement function of Coenzyme Q10 on body weight changes rblood serum biochemical parameters in resembling type 2 diabetic male rats. J App Pharm Sci, 2017; 7 (01): 114-119. 